\title{
OPTIMIZATION OF THE LESSONS LEARNED PROCESS IN THE CZECH ARMED FORCES
}

\author{
Janka KOSECOVÁ \\ University of Defence, Brno, Czech Republic \\ janka.kolacnakosecova@unob.cz \\ Kateřina KAŠPÁRKOVÁ \\ University of Defence, Brno, Czech Republic \\ katerina.kasparkova@unob.cz
}

\begin{abstract}
Lessons learned process enables an organization to learn from its mistakes and successes. Thanks to this process an organization can reduce the risk of repeating mistakes and increase the chance that successes are repeated. This article aims to present the results of the research, especially, results of the process analysis of sharing lessons in the Czech Armed Forces. Based on the procedural deficiencies identification, benchmarking comparisons with lessons learned process of other organizations were carried out. The purpose of the benchmarking was to do away with the above mentioned deficiencies. To use benchmarking was beneficial from the point of view of a simplified model processing. The final part of the article introduces set of recommendation including the optimized model of the lessons learned process.
\end{abstract}

KEYWORDS: benchmarking, lessons learned, optimization, optimized, process analysis

\section{Introduction}

The object of the research is lessons learned process (LL), which is an important tool for commanders. They can use it in their decision making process. The chosen issue was researched using process analysis of process settings. It was analysed from the point of view of factual and logical correctness. A process modelling for instructive depiction of the lessons learned process was used as well. The application of benchmarking with chosen LL process was beneficial to a simplified model processing. The set of recommendations to optimize the process including the optimized model of the LL process is introduced in this article. The results of this research allow optimizing the use of the
LL process, provided that the results will be supported and accepted by the top management of the Ministry of Defence (MoD) and Armed Forces of Czech Republic (ACR).

\section{Research Methodology}

In the first phase of the research, the method of a structured interview was used. Then, to achieve relevant data and information in order to be able to analyse the current state of examined problems, a questionnaire survey was used. Analysis of process control regulators was conducted for the reason of further data processing, which was achieved.

The organization's strategy and the interest stakeholder analysis were used to 
identify those stakeholders who have great power of influence. During the research, benchmarking as a science method was applied and this article focuses more on this part of the research. In order to suggest an optimized model of LL process, benchmarking as a science method was used. Benchmarking is the process of comparing the practices of one's own organisation against the best practices and experiences of comparable organisations that are leaders in their field. The authors chose LL process of the international Organization for Standardization (ISO), particularly its standard for lesson learned in space systems, the United States Department of Defense and the Canadian Armed Forces. The results of research were introduced in Land Forces Academy Review No. 1/2016 and No. 1/2017.

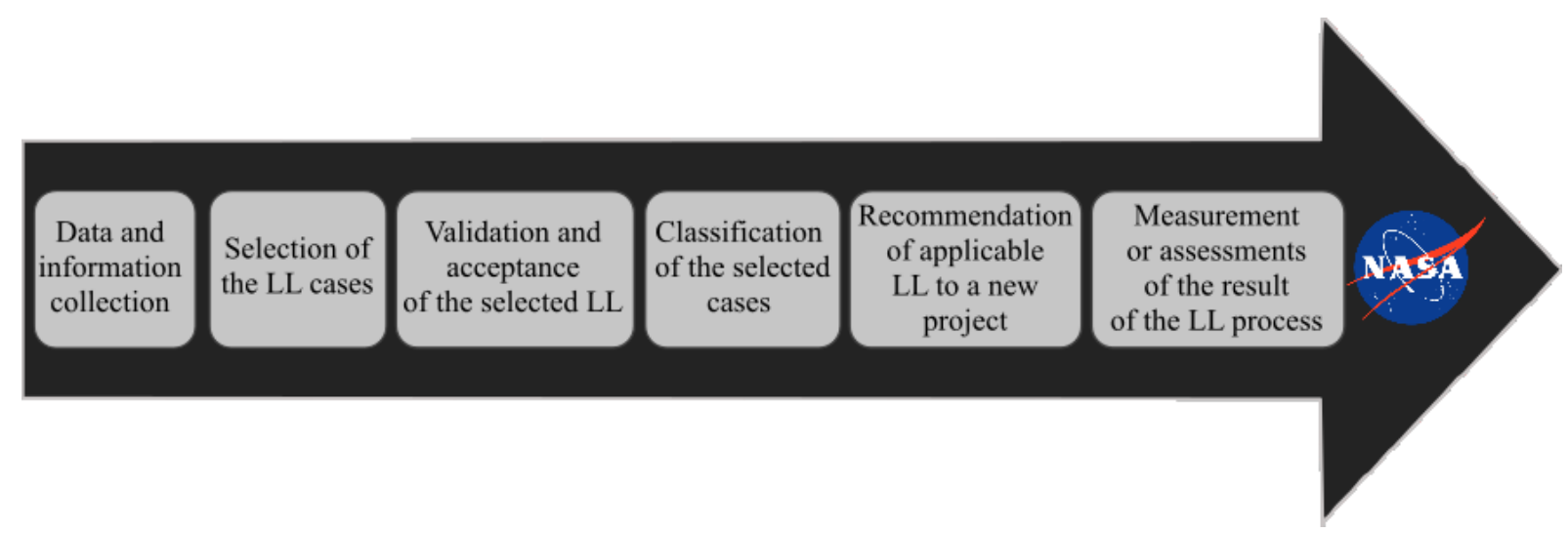

Figure no. 1: Process stages

(Source: International Organization for Standardization, 2010)

\subsection{Results of Benchmarking with ISO Standard 16192:2010}

The International Organization for Standardization (ISO) is a worldwide federation of national standards bodies which develops international standards through the work of technical committees.

ISO Standard 16192:2010 on "Space Systems - Experience Gained in Space Projects (Lessons Learned) Principles and Guidelines" was drafted by the ISO in 2010. This standard is relevant because organisations involved with space Systems are what are known as "High Reliability Organisations". That is, they have a very low tolerance for failure, because the stakes are so high. The drastic consequences of errors or mistakes do not allow learning through trial-and-error. ISO Standard 16192:2010 explains the role of a lessons learned activity. It suggests templates for generic lessons learned and contains an abbreviated LL process.
The process described in the ISO standard is quite generic and easy to follow. It includes steps which can be seen in Figure no. 1.

\section{Strengths:}

The main outputs of these activities are (1) an identification of the root cause of the event; (2) a description of the lesson learned; (3) a list of recommendations for the future.

Terminology is simple, only term lessons is used. Knowledge management system (KMS) called the Joint Lessons Learned Information System (JLLIS).

The standard 16192:2010 is used in National Aeronautics and Space Administration (NASA) and knowledge management system (KMS) is function and called Lessons Learned Information System (LLIS). 


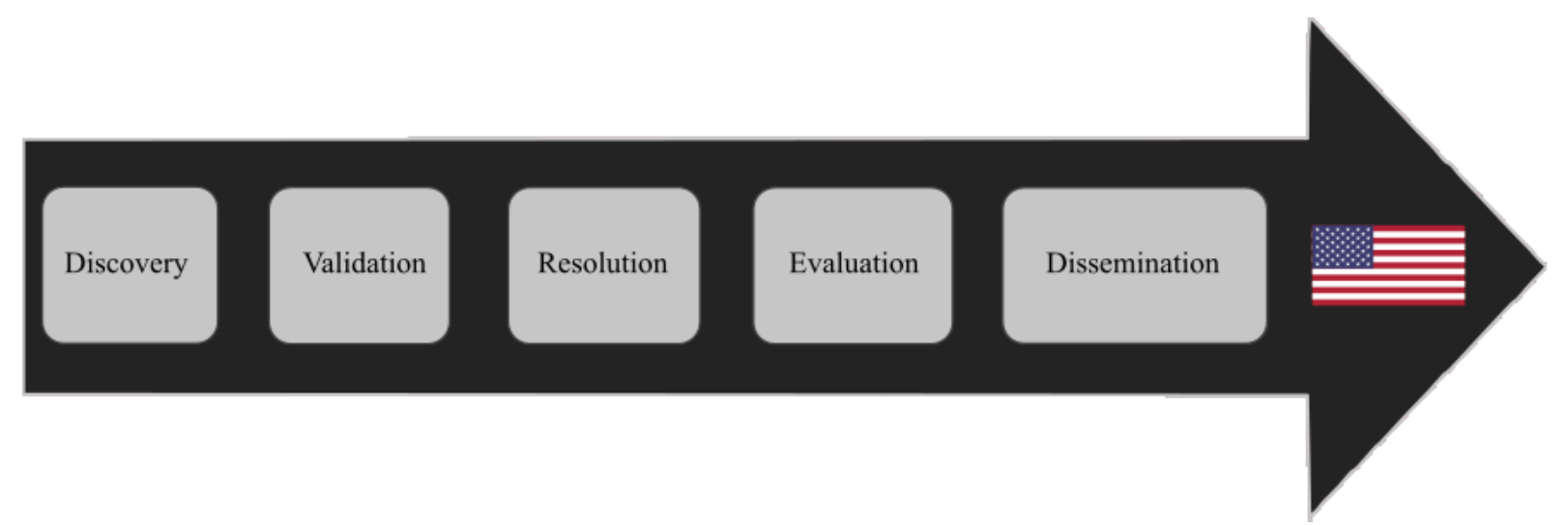

Figure no 2: Process stages

(Source: Chairman of the Joint Chiefs of Staff Instruction 3150.25F, 2015)

\subsection{Results of Benchmarking with Lessons Learned Process of the United States Department of Defense}

The Unites State Department of Defense (US DoD) is a large, diverse organization, consisting of five military Services and a host of civilian organizations, supporting structures and agencies.

The US Military has developed a robust, comprehensive system to capture, analyze, and disseminate tactical and operational level Lessons Learned from training events and ongoing conflict operations. These agencies have developed their own Lessons Learned programs (LL). Individual organizations have their own LL programs and are able to fully provide the tasks of collecting LL, their processing and their subsequent sharing and dissemination. Despite this, it was necessary to create a regulated system which is required to produce shareable, actionable joint lessons learned. For this reason the Joint Center for Lessons Learned (JCLL) was established including the US Joint Lessons Learned Program (JLLP). In order to control the whole program, the JLLP's guidance directive CJCSI $3150.25 \mathrm{~F}$ was issued. This directive is regularly updated. Later, the JCLL was changed to Joint Centre for Operational Analysis and Lessons Learned (JCOA-LL). The JLLP is a knowledge management activity focused on improving joint preparedness and performance.
The main aim of the JLLP is to develop the United States' joint capabilities by contributing to improvements in doctrine, organization, training, materiel, leadership and education, personnel, facilities (DOTMLPF). Current stakeholders are the Joint Staff (JS), Services to include the Reserve Components (RC), Combatant Commands, Combat Support Agencies (CSA), National Guard (NG), and other organizations participating in joint activities. Sharing of joint lessons learned is supported by a knowledge management system (KMS) called the Joint Lessons Learned Information System (JLLIS). This KMS tool was implemented in 2006. According to the report to Congressional Committees: "DOD organizations do not consistently use the Joint Lessons Learned Information System to share lessons learned due to the system's limited functionality. For this reason it is recommended to improve JLLIS's functionality" (United States Government Accountability Office, 2015). The process model, which is depicted in Figure no. 2, consists of five stages. The stage which includes collecting observations is called the discovery phase. This phase is the start of the lessons learned process. Activities in this phase include collecting information, summaries, and reports through active and passive means. This phase is generally known as collection phase. During next 
phases discovered lessons and best practices can be validated, integrated, and evaluated. In a case when is necessary is to the ability to resolve issues and implement corrective actions.

\section{Strengths:}

The undisputed advantage is that the US DoD sets out the principles of Army Knowledge Management Principles (2008) including the principles of LL programs, and each armed forces component has an appropriate control regulator. The umbrella LL program is the JLLP. Each approved LL program is elaborated in detail and a corresponding organizational structure is established with the allocation of the necessary service positions. This approach provides professional service of trained experts for the given issue and does not unnecessarily overload the individual commanders. JLLIS as a KMS tool is used to share those processed lessons learned.

Knowledge collection is done both formally and informally, on the basis of a processed knowledge collection plan which uses knowledge acquired from selected jobs. It is then followed by a quality analysis. Terminology is understandable and includes terms such as observation, lesson and lesson learned.

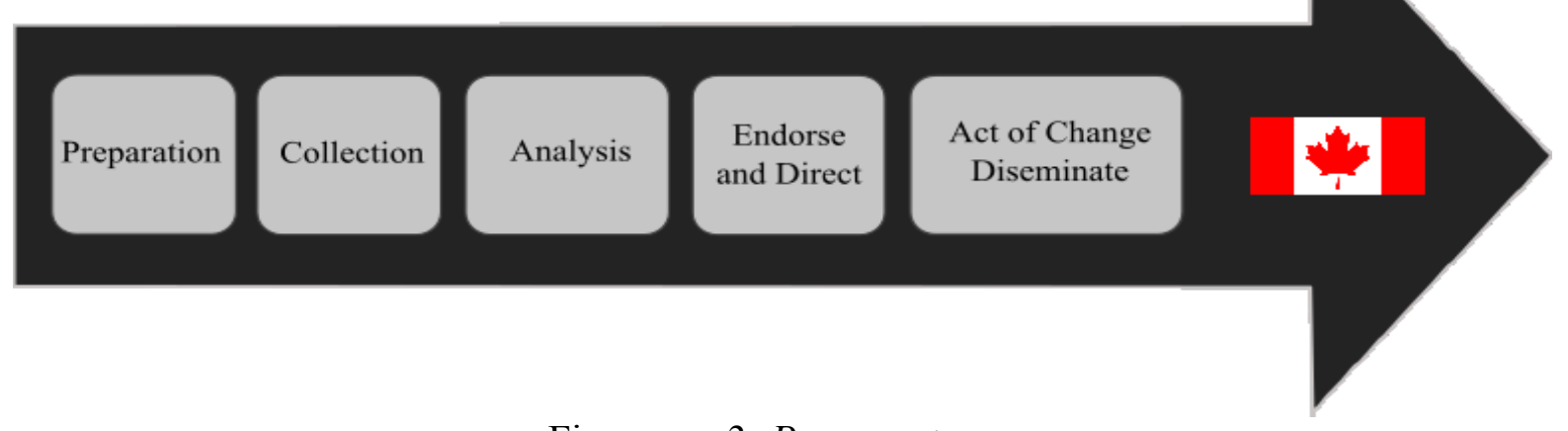

Figure no. 3: Process stages

(Canadian Forces Warfare Centre, 2015)

\subsection{Results of Benchmarking with} Lessons Learned Process of the Canadian Armed Forces

Defence Administrative Orders and Directives (DAOD) 8010-0, Lessons Learned is a directive that applies to employees of the Department of National Defence (DND employees) and an order that applies to officers and noncommissioned members of the Canadian Armed Forces (CAF members). This directive was issued in 2004 and the last modified in 2016. Programmes in individual units of the Canadian armed forces follow this directive. This directive is approved by Deputy Minister of National Defence and Chief of the Defence Staff. Commander Canadian Joint Operations
Command (Comd CJOC) is CAF authority to coordinate LL activities, and to support and maintain the LL program.

The Canadian Army, the Royal Canadian Air Force, and the Royal Canadian Navy maintain lessons learned programmes. Although these programmes are unique to each environment, all rely on the chain of command to steer implementation and execution, assisted by qualified lessons learned staff officers (LLSOs). The Joint Lessons Learned Process is divided into five steps depicted in Figure no. 3. The process is started by the first phase "preparation". During this phase, the LL plan is created to support the commander's intent for a given situation. Now, the way of collecting data and 
information is planned in detail. For example, questionnaire survey, interviews, or other methods are used. As a part of the plan, all participating organisations are identified and assured that the plan is a supporting element of the process. The development of collection plan is divided in the eight steps and it is a significant part of the process. Then, the analysis phase is set up. This phase is carried out in a similar way as in other examined organizations together with the use of specialists. In step four, the changes authority approves, modifies, or rejects staff recommendations and advises the submitting organizations. In case these recommendations are approved, this authority directs change and assigns resources to effect the change. In step five, the change authority implements the change and then must validate that the corrective action is achieving the desired effect.

The specificity of this process includes setting, so called, change authority. The change authority is an individual empowered to approve changes at the appropriate level of command. Its role is to analyse issues and determine if changes are necessary. Furthermore, initiates an action that corrects the fault that is identified. This authority also instigates corrective action within the responsibility area by other organizations.

\section{Strengths:}

It can be evaluated that in the Canadian LL system the emphasis is put on preparing the use of the process and collecting observations, thus greatly increasing the efficiency of the whole process. Also, when the collected observations are processed, the authority of change is determined. The Authority of change has an irreplaceable role but does not replace the role of commanders and other stakeholders (for example Subject Matter Expert), only supports the good use of the process as a whole. Terminology is similar to the one used in LL process
NATO and uses the terms observation, lesson, lesson identified and lesson learned. The processed lessons learned, as the resulting product of the process, are shared using KMS.

\section{Process Analysis and Research Evaluation}

The aim of the research was to analyse contemporary state of the LL process model within the MoD and ACR. The aim was certainly accomplished and finally key barriers were defined (Figure no. 4). Thus, the conditions for further issue elaboration and consequent steps necessary to conduct optimization of the given process were established. Results gained by relevant methods application provide answers to research questions with sufficient preconditions for key barriers identification. The research implies that the LL process has already been started but it has to confront barriers that need to be overcome. These are some of them:

- The road that leads from "observation" to "lesson learned" contains many stages in the current process. The problem is translating lesson identified (LI) to lesson learned. One of the main causes is that the process is seen as unmanageable, with the implementation and validation phases in particular taking too long time. Data from the all-department LL database confirm this problem. Database contains 681 records as a whole, but only 23 events have been finished as lesson learned.

- The terminology used in this process is unclear for ordinary staff members, the difference between lesson identified and lesson learned is far from obvious.

There is a barrier represented by low support coming from senior executives. "Cooperation between commanders/ directors and officer of primary responsibility (OPR) does not work at all. The LL process is not understood as a 
multi-discipline matter which brings about profit to all participants, and which requires an active, consistent, and responsible approach from all participating elements. Not only OPR's have contributed to this state but so have their commanders" (Náčelník generálního štábu Armády České republliky, 2015). What is more, trained OPR are very often promoted; then, by virtue of their new authorities and responsibilities they have in their new positions, they are able to manage the LL process competently.

- The next barrier is sharing the LL process results, which is a basic precondition for disseminating valuable lessons learned and leads to the permanent process of increasing performance efficiency of the organization. Sharing must be pointed in order to allow the Lessons Learned reach all users who need them in a given time. At present time the personnel is not sufficiently informed on the possibility to use the important tool of the LL process - the all-department LL database. That is how further limitation of the process arises and the results are

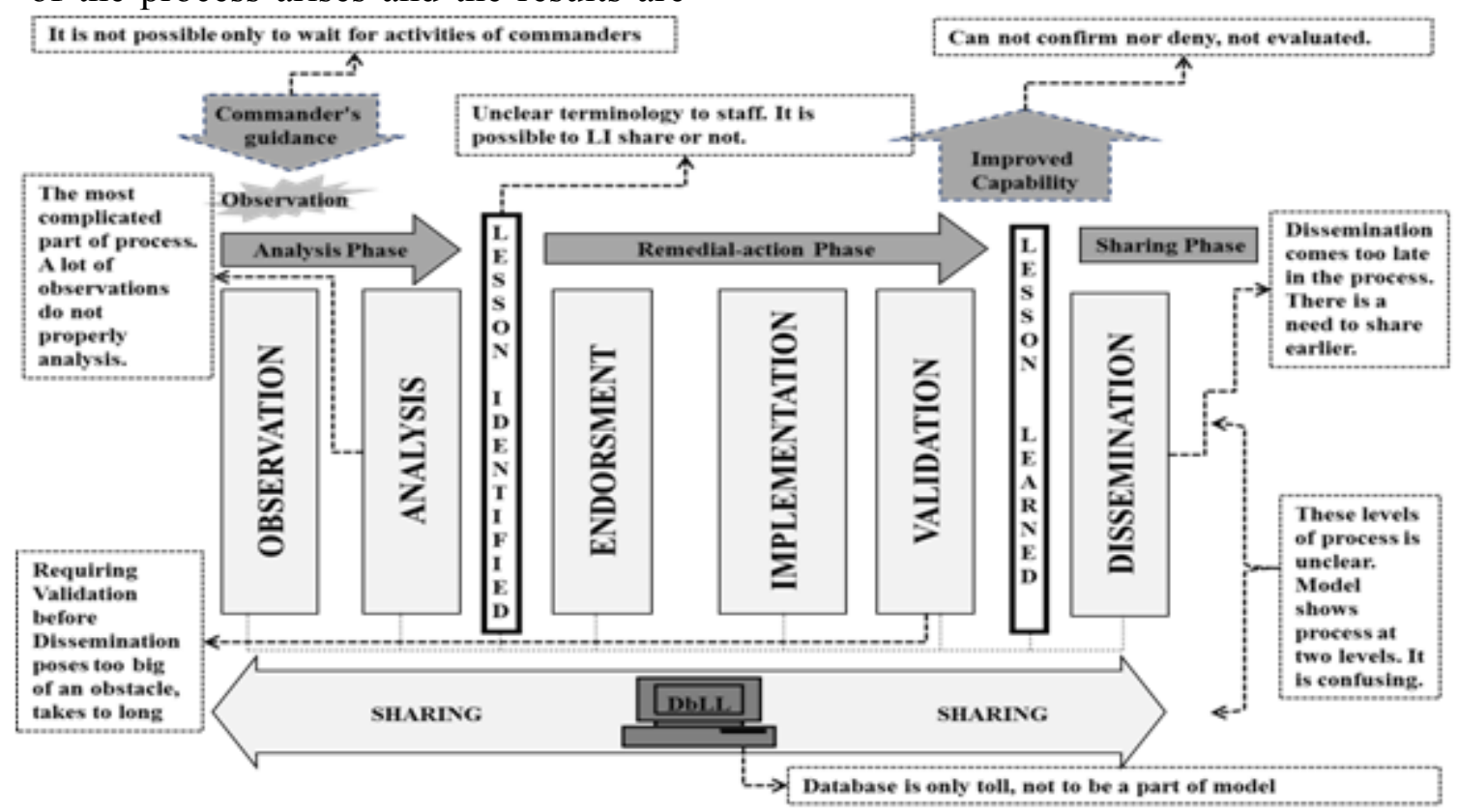

Figure no. 4: Model of LL process in the ACR including barriers

(Source: authors) not shared in a corresponding way. From a complex point of view, the sharing phase is not dealt with in a conceptual way; individual workplaces within the Defence Department use their own data storage and a great deal of users is not sufficiently informed about the possibility to use the data storage. This barrier was a subject of negotiation at the LL process workshop taking place in November, 2014 at the Training Command - Military Academy Vyskov, where the workshop record reads: "On the one hand commanders do not like sharing their opinions; on the other hand there is not very active, cautious, even evasive approach of OPRs" (Náčelník generálního štábu Armády České republiky, 2015).

- All the above mentioned barriers must be analysed in more detail. Measures and recommendations must be worked out in order to get rid of the barriers. This is the only way how the Defence Department can create favourable environment suitable for sharing the acquired knowledge and experiences. 
4. Recommendations for Further Optimizations of the Ll Process in the Czech Armed Forces

Current state of the LL process in the ACR is a good starting point for its further development despite of all the barriers mentioned above. The next paragraphs describe measures, which, if put into practice, will help rationalize and increase efficiency of further development of the ACR:

Adopt an optimized process model (Figure no. 5).

The new model accomplishes several important objectives:
- It shows that "lessons" should be consulted when a staff plans all of their activities;

- It clarifies that the process applies to both routine business as well as special events, such as military operations or exercises;

- It enables early sharing of lessons, even before full implementation and validation;

- It uses the generic term "lesson", eliminating the distinction between "lessons identified" and "lessons learned".

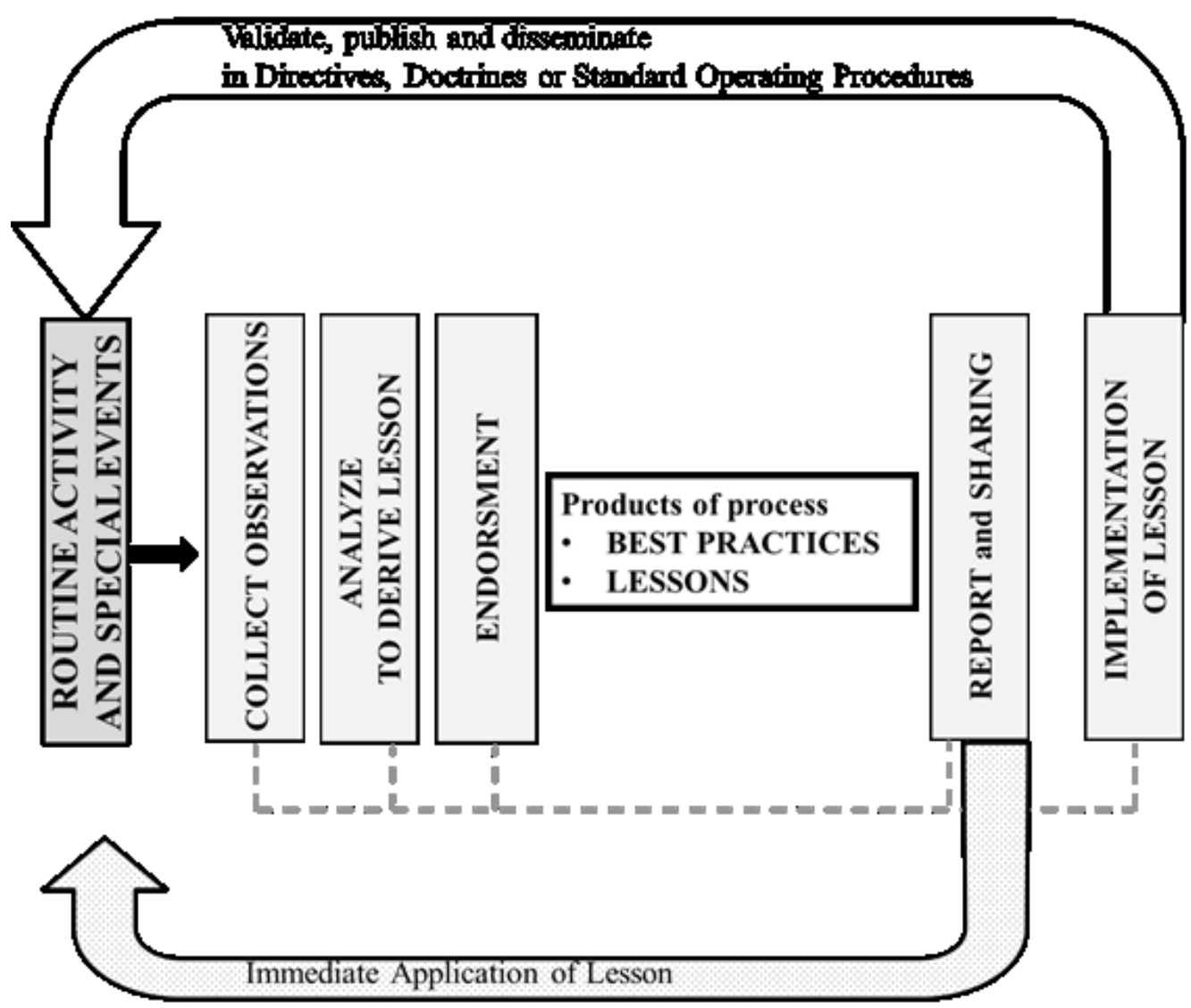

Figure no. 5: Optimized model of LL process

(Source: authors)

- Create conditions for OPR activities.

It means to create some time space for OPR at troops, units, and staffs of the ACR. This can be achieved by selecting suitable people who will devote their time to collecting and processing
Lessons Learned beyond the scope of their duties, or by creating new service posts for OPR at brigade staffs, and at the Joint Operations Centre of the Ministry of Defence of the Czech Republic (JOC MoD). 
- Support sharing and dissemination of processed lessons learned. Currently, there is no publication which keeps records of acquired LL within a given period coherently. The Centrum of Doctrine (CDo) should publish a quarterly bulletin to inform about activities in this field.

\section{Conclusions}

Implementing the LL process within the MoD is built on a strong foundation. Since it is based on people throughout the whole structure of the armed forces as well as in strategic control bodies, development of the LL process, as a tool of command and control, will take many years and will depend on creating a healthy organizational structure. As in other fields, this process will function only when people understand its importance and tangible results will be seen. Otherwise, professional soldiers will perceive this process as an unnecessary administrative burden. Nevertheless, without the support of the top representatives of the $\mathrm{MoD}$ and commanders at all levels, the process cannot be successfully implemented; it would be further used in a formal way. The CDo, Vyškov workplace, which must be filled with experienced workers, must stay the main driving force of the process. Introducing the optimized model of the LL process can mean faster input event processing and creating the required result which is, in this case, a lesson learned. This model is suitable for use at tactical and operational level.

\section{REFERENCES}

Canadian Forces Warfare Centre. (2015). B-GL-025-0A2/FP-001 Canadian Forces Joint Publication: CJPF A2 Lessons Learned. Otawa: Joint Doctrine Branch.

Chairman of the Joint Chiefs of Staff Instruction (CJCSI 3150.25F). (2015). Joint Lessons Learned Program. Washington DC.

International Organization for Standardization. (2010). Space systems - Experience gained in space projects (Lessons learned) - Principles and guidelines: ISO 16192:2010. Geneva, Switzerland.

Náčelník generálního štábu Armády České republiky. (2015). Zpráva o stavu v oblasti získávání poznatků a využivání zkušeností v AČR za rok 2014. Praha.

Náčelník generálního štábu Armády České republliky. (2015). Nařizení Náčelníka generálního štábu AČR $k$ rozvoji procesu ziskávání poznatků a využivání zkušeností AČR: Čj. 37-7/2015-1122. Praha: Generální štáb Armády České republiky.

United States Army Combined Arms Center. (2008). Army Knowledge Management Principles. Kansas, available at: http:// usacac.army.mil/ cac2/ AOKM/ aokm2008/ A4\%20Doc\%201\%20AKM\%20 Principles \%2025\%20JUN\%2020081.pdf.

United States Government Accountability Office. (2015). GAO-15-243 OCS Lessons Learned: Operational Contract Support. Actions Needed to Enhance the Collection, Integration, and Sharing of Lessons Learned. Washington, DC. 